\title{
DIE HOUDINGS EN KENNIS VAN DIE PLAASWERKER-GEMEENSKAP TEN OPSIGTE VAN MIV/VIGS
}

\author{
C Strydom, L Nogueira, AA Roux
}

\section{PROBLEEMSTELLING}

Ongeveer 6 miljoen Suid-Afrikaners, van wie $26 \%$ volwassenes is, sal binne die volgende ses jaar MIV-positief wees, teenoor 0,1\% in 1990 (Department of Health, 2004; Pelser, 2004:14; UNAIDS, 2004). Die tendens is dat MIV/VIGS veral in landelike gebiede toeneem (Department of Economic Development and Tourism, 2004:57). Volgens Human Sciences Research Council of South Africa (2003) is die verspreiding van MIV in sekere gebiede soos volg: $21,3 \%$ in stedelike informele nedersettings, $12,1 \%$ in formele nedersettings, $58,7 \%$ in stamgebiede en 7,9\% in plaasgebiede (Pelser, 2004:14). Luidens 'n verslag van die Verenigde Nasies se voedsel- en landbou-organisasie (VLO) is sowat 7 miljoen plaaswerkers in Afrika sedert 1985 aan VIGS-verwante siektes oorlede (Louw, 2004:14; USAID, 2002). Projeksies toon aan dat Suid-Afrika teen 2020 20\% van sy plaaswerkers aan VIGS-verwante siektes sal verloor (Department of Economic Development and Tourism, 2004:57). MIV is dus vir boere een van die grootste bedreigings (Pelser, 2004:5).

Die produktiwiteit van die landbou-arbeidsmag is die lewensbloed van ontwikkelende lande, spesifiek van Suid-Afrika. Voedselvoorsiening en ekonomiese groei is grootliks afhanklik van die sukses van die landbousektor. In talle ontwikkelende lande verwoes die MIV-epidemie kleinboere en benadeel dit voedselproduksie (Schram, 2004:15). Volgens dieselfde outeur verander die voedselsituasie van 'n surplus tot 'n skaarste, soms selfs tot 'n tekort.

Die plaaswerkergemeenskap beskik nie noodwendig oor die nodige infrastruktuur om die epidemie van MIV/VIGS hok te slaan nie. Slegs $10 \%$ van die bevolking wat laasgenoemde benodig, het toegang tot die dienste en is dus onbewus van hul status (Furber, Hodgson, Desclaux \& Mukasa, 2004:3).

Negatiewe gevoelens heers ook ten opsigte van hulpverlening aan die geïnfekteerde en sy gesin. In 'n studie oor die houdings en voorkeure van gesinne op plase om professionele hulp met betrekking tot MIV/VIGS-aangeleenthede te vra, is vasgestel dat gevoelens soos verleentheid en vrees 'n integrale rol speel (Rounds, Galinsky \& Stevens, 1991:6).

Uit bogenoemde blyk dit duidelik dat die plaaswerker opgevoed moet word met betrekking tot die omvang van MIV/VIGS sodat negatiewe gevoelens oor hulpverlening en stigmatisering uit die weg geruim kan word. Die plaaswerkergemeenskap moet bewus gemaak word van hulpbronne en -dienste wat vir hulle beskikbaar is. Ryke (2004:54) sê die volgende in hierdie verband: "Farm dwellers' contact outside the farm setting is very limited."

Uit die voorafgaande is die volgende vraag geformuleer:

- Wat is die houdings, oortuigings en kennisvlak onder die swart plaaswerkers ten opsigte van MIV/VIGS vanuit hul sosio-kulturele agtergrond?

\section{DOELSTELLING EN DOELWITTE}

Die doelstelling was soos volg:

- Om die houdings, oortuigings en kennisvlak onder die plaaswerker-gemeenskap ten opsigte van MIV/VIGS te ondersoek. 
Die doelwitte was as volg:

- Om aan die hand van 'n literatuurstudie die houdings, oortuigings en kennisvlak van swart plaaswerkers ten opsigte van MIV/VIGS vas te stel.

- Om aan die hand van 'n empiriese ondersoek die houdings, oortuigings en kennisvlak ten opsigte van MIV/VIGS te ondersoek.

\section{NAVORSINGSMETODOLOGIE}

\section{Ontwerp}

Die navorsingsontwerp is hoofsaaklik verkennend. Volgens De Vos, Strydom, Fouche en Delport (2005:106) word hierdie ontwerp gebruik as 'n bekende onderwerp voorkom waaroor min inligting bestaan.

'n Literatuurstudie is gedoen oor die kennisvlak en houdings ten opsigte van MIV/VIGS. Heelwat data is beskikbaar oor MIV/VIGS, maar inligting spesifiek oor die plaaswerkergemeenskap is beperk. Verskeie databasisse van die Ferdinand Postma Biblioteek is vir die ondersoek gebruik. Die databasisse Ebscohost, Internet en Ferdikat is benut. Verskeie boeke en vaktydskrifte is ook bestudeer.

\section{Respondente}

Tydens die ondersoek is daar van die toevallige steekproef gebruik gemaak (De Vos et al., 2005:202; Grinnell, 1993:162). By hierdie tipe steekproef is die proefpersone meestal diegene wat die naaste en die beskikbaarste is.

Die steekproef het bestaan uit 100 swart volwassenes uit die plaaswerkergemeenskap in die Kroonstad-Bothaville-distrik. Vyf plase wat bereid was om deel te neem aan die ondersoek is betrek. Die egpare van tien huishoudings op elke plaas is geselekteer op grond van hulle bereidwilligheid.

\section{Meetinstrument}

Daar is van die opnameprosedure gebruik gemaak om die kennisvlak en die houdings van plaaswerkers ten opsigte van MIV/VIGS vas te stel. Verwante veranderlikes soos inkomste, huwelikstaat en omstandighede in huishoudings is hierby ingesluit. Volgens Royse (1995:146) word hierna verwys as "behoeftebepaling".

'n Eenvoudige, selfopgestelde skedule is tydens die ondersoek gebruik. Volgens die Nuwe Woordeboek vir Maatskaplike Werk (1995:60) is 'n skedule 'n stel vrae op 'n vorm wat 'n ondervraer aan 'n respondent stel en waarvan die antwoorde deur die ondervraer opgeteken word. Kwalitatiewe en kwantitatiewe inligting is bekom aangaande die kennisvlak en houdings van plaaswerkers ten opsigte van MIV/VIGS. Die skedule is opgestel nadat soortgelyke metingskale in ander ondersoeke bestudeer is (Makhubele, 2004:184-192; Podile, 2004:23-27; Raath, 2001:Addendum A; Strydom, 2002:395-399). Die Statistiese Konsultasie Dienste van die Noordwes Universiteit het die skedule vir geldigheid en betroubaarheid getoets. Die skedule is persoonlik deur die navorsers met die respondente voltooi. 'n Opgeleide tolk was byderhand om behulpsaam te wees met die vertaling.

\section{Etiese Aspekte}

Volgens De Vos et al. (2005:30) moet die hele navorsingsprojek eties korrek geskied. Die navorser moet kultuurverskille van gemeenskappe in al sy handelinge respekteer ten einde die samewerking van die gemeenskap te verseker.

Aandag is aan die volgende etiese aspekte geskenk: 
- Ingeligte toestemming;

- Skade aan die respondent en/of die eksperimentele subjekte;

- Skending van privaatheid;

- Vertroulikheid;

- Vrywillige deelname.

Die projek is deur die Etiekkomitee van die Noordwes-Universiteit (Potchefstroomkampus) goedgekeur. Die verwysingsnommer is $05 \mathrm{K07}$.

\section{Data analise}

Die kwantitatiewe data is deur die Statistiese Konsultasie Dienste van die NoordwesUniversiteit (Potchefstroomkampus) geanaliseer met behulp van die SAS System for Windows Release 9.2 TS Level 1MO programme (SAS Institute, 2005). Die kwalitatiewe data is deur die navorsers georden en geklassifiseer.

\section{RESULTATE}

\section{PROFIEL VAN DIE RESPONDENTE}

\section{Huistaal}

Uit die gegewens blyk dit dat 94 (94\%) respondente Suid-Sotho-sprekend is, 2 (2\%) Xhosasprekend, 2 (2\%) Setswana-sprekend, 1 (1\%) Zoeloe-sprekend en 1 (1\%) Ndebele-sprekend. Die navorser was die resultaat te wagte, aangesien die Vrystaat Provinsie se inwoners merendeels Suid-Sotho-sprekend is.

\section{Grootte van huishoudings}

TABEL 1

GROOTTE VAN DIE HUISHOUDINGS

\begin{tabular}{|l|c|c|}
\hline \multicolumn{1}{|c|}{ Aantal kinders } & $\mathbf{N}$ & \% \\
\hline Geen & 22 & 22 \\
\hline Een & 21 & 21 \\
\hline Twee & 18 & 18 \\
\hline Drie & 18 & 18 \\
\hline Vier & 7 & 7 \\
\hline Vyf & 2 & 2 \\
\hline Meer as vyf & 12 & 12 \\
\hline Totaal & 100 & 100 \\
\hline
\end{tabular}

Uit die tabel blyk dit dat daar heelwat kinders betrokke is. Dit is dus belangrik dat die kennis van die plaaswerker ten opsigte van MIV/VIGS moet uitbrei, anders kan die kinders van die plaaswerkers moontlik deel uitmaak van die getal weeskinders. Volgens Wessels (2003:80) was daar in Suid-Afrika in 2001 reeds 420000 weeskinders as gevolg van VIGS, en in die jaar 2008 sal daar na raming 1,6 miljoen VIGS-weeskinders wees. Gedurende die volgende twintig jaar sal 'n toename in weeskinders steeds voorkom.

\section{Huwelikstaat}

Die huwelikstaat van hierdie plaaswerkers is soos volg:

- Respondente in die huwelik bevestig (32\%);

- Respondente in saamblyverhoudings (55\%);

- Respondente wat nie by 'n verhouding betrokke is nie (13\%). 
Poligamie (om meer as een vrou te hê) is ook 'n kulturele faktor wat 'n groot invloed het op die verspreiding van MIV/VIGS. Alhoewel baie lande deur die Europese sisteem wat monogamie aanmoedig, beïnvloed is, verkies die tradisionele Afrika-sisteem die poligame huwelik (Buseh, Glass \& Mcelmurry, 2001:120). Volgens Roux (2002:75) dui die groot getal saamblyverhoudings daarop dat die kanse groot is dat respondente meer as een bedmaat sal hê, en dit lei tot die verspreiding van MIV/VIGS.

\section{Kerkbywoning}

Aan die respondente is slegs gevra of hulle kerk toe gaan, waarop 85\% "ja" geantwoord het en $15 \%$ "nee". Die gemeenskap heg waarde aan godsdiens en dit dra by tot die goeie morele waardes van die gemeenskap. Laasgenoemde is 'n belangrike faktor in die voorkoming van MIV (Roux, 2002:313).

\section{Inkomste van die plaaswerker}

Die inkomste van die plaaswerker word soos volg weergegee:

TABEL 2

INKOMSTE VAN DIE PLAASWERKER

\begin{tabular}{|c|c|c|c|}
\hline \multicolumn{2}{|c|}{ Rand per maand } & Frekwensie & $\%$ \\
\hline 100 & $-\quad 200$ & 1 & 1 \\
\hline 201 & $-\quad 300$ & 2 & 2 \\
\hline 301 & $-\quad 400$ & 3 & 3 \\
\hline 401 & $-\quad 500$ & 12 & 12 \\
\hline 501 & $-\quad 600$ & 18 & 18 \\
\hline 601 & $\begin{array}{l}-\quad 700 \\
\end{array}$ & 17 & 17 \\
\hline 701 & $-\quad 800$ & 21 & 21 \\
\hline 801 & -900 & 6 & 6 \\
\hline 901 & -1000 & 8 & 8 \\
\hline 1000 & -1200 & 8 & 8 \\
\hline 1400 & -1900 & 4 & 4 \\
\hline Totaal & & 100 & 100 \\
\hline
\end{tabular}

Die inkomste van die plaaswerkers wissel dus tussen R120 en R1 900 per maand. Baie van die plaaswerkers werk slegs in die plant- en/of oesseisoen. Meer as 33 respondente verdien onder R600,00. Slegs 12 respondente verdien meer as 'n R1 000,00. Die gemiddelde inkomste van die plaaswerker is R690,00. Die inkomste van die plaaswerker is dus baie laag. Ryke (2004:48) beaam hierdie feit met die volgende opmerking: "Farm dwellers experience their income as inadequate to meet the demands of the high cost of living. Inadequate income was generally attributed to low wages of farm workers and underemployment of women." Volgens Strydom, Cronje, Roux, Strydom en Wessels (2005:71) word die arm deel van die bevolking beskryf as mense wat minder as R355 per maand per volwassene ontvang, terwyl ultra-armes minder as R194 per maand per volwassene ontvang. As die ouers nie daartoe in staat is om hul gesin finansieel te onderhou nie, het dit tot gevolg dat die gesin se lewenstandaard sal daal. Dit gaan gepaard met 'n behuisings- en voedseltekort en hoë mediese koste, en saam bring dit afhanklikheid van ander mee (Strydom \& Strydom, 2004:325).

Strydom (2002:248) is van mening dat armoede die grootste algemene faktor is wat aanleiding gee tot die oordrag van MIV. Mense wat ekonomies gedepriveer is, het beperkte toegang tot opvoeding, sosiale en mediese dienste en ander vorme van sosiale en finansiële ondersteuning. 


\section{Geletterdheid}

Die geletterdheidsvlak van die plaaswerker is soos volg:

\section{TABEL 3}

GELETTERDHEIDSVLAK

\begin{tabular}{|c|c|c|}
\hline Geletterdheidsvlak & Getal Respondente & \% Respondente \\
\hline Geen skoolopleiding nie & 6 & 6 \\
\hline Graad 2 & 2 & 2 \\
\hline Graad & 5 & 5 \\
\hline Graad & 6 & 6 \\
\hline Graad & 7 & 7 \\
\hline Graad & 10 & 10 \\
\hline Graad & 21 & 21 \\
\hline Graad & 14 & 14 \\
\hline Graad 9 & 10 & 10 \\
\hline Graad 10 & 15 & 15 \\
\hline Graad 11 & 2 & 2 \\
\hline $\begin{array}{ll}\text { Graad } 12 \\
\end{array}$ & 2 & 2 \\
\hline
\end{tabular}

Slegs $2 \%$ van die respondente het Graad 11 en $2 \%$ het Graad $12 \%$ voltooi. Die lae geletterdheidsvlak van plaaswerkers asook die beperkte infrastruktuur moet dus in ag geneem word, aangesien opvoeding 'n belangrike rol speel in die voorkoming van MIV/VIGS. Evian (2000:21) bevestig dit met die volgende stelling: "Ongeletterdheid weerhou individue grootliks van toegang tot kennis aangaande MIV/VIGS." Rispel (2006:9) skryf die volgende in hierdie verband: "Schooling reduces HIV risk as it increases knowledge of the disease and is correlated with changes in sexual behaviour".

\section{KENNIS OOR DIE SIEKTE}

\section{Beskrywing van die term MIV/VIGS}

Op die vraag waarby respondente moes verduidelik wat MIV/VIGS is, is die volgende verduidelikings gegee:

- Ek weet nie wat MIV/VIGS regtig is nie (65\%);

- MIV/VIGS is 'n siekte wat tydens seksuele omgang deur "vuil bloed" oorgedra word $(16 \%)$;

- MIV/VIGS is die gevolg van verskeie bedmaats (7\%);

- MIV/VIGS is 'n siekte wat mense doodmaak (5\%);

- MIV/VIGS is 'n siekte wat met fisiese simptome gepaard gaan, soos hoofpyn, diarree en maagpyn (4\%);

- $\mathrm{MIV/VIGS} \mathrm{is} \mathrm{'n} \mathrm{siekte} \mathrm{in} \mathrm{die} \mathrm{bloed} \mathrm{(2 \% );}$

- MIV/VIGS is 'n straf van God aan mense wat losbandig leef (1\%).

Die plaaswerker se beskrywing van die term MIV/VIGS is onakkuraat. Die rede kan wees dat elementêre woorde soos kondoom, virus en immuunstelsel in talle van die Afrika-tale se woordeskatte nie bestaan nie (Berstein \& Van Rooyen, 1994:377).

In die ondersoek van Roux, Venter en Wessels (2001:35) Seyama (2006:12) en Strydom (2000:198) is ook bewys dat respondente se kennis ten opsigte van MIV/VIGS veral in plattelandse gebiede beperk is en hul omskrywings van die virus ook baie vaag is. 


\section{Respondente se mening oor die toename in MIV/VIGS}

Die stelling dat MIV/VIGS toeneem, is deur $87 \%$ van die respondente beaam. Die volgende redes is verstrek:

- $61 \%$ het verwys na die toename in sterftesyfer wat deur die media bekend gemaak word;

- $7 \%$ het persoonlike ervaring en waarneming, byvoorbeeld van mense wat baie maer is, of van ' $n$ vriend of familielid wat aan die virus oorlede is as motivering vir die stelling gegee;

- $8 \%$ was van mening dat meer mense vandag sterf as vroeër, en VIGS as verklaring vir die verskynsel gegee;

- $7 \%$ was van mening dat baie mense siek is en nie gesond word nie, en die virus as die enigste rede daarvoor sien.

Elf persent het die stelling teengestaan met argumente soos dat getalle deur die media oordryf word $(5 \%)$ en dat die siekte nie werklik bestaan nie (3\%). Slegs $2 \%$ het gesê dat hulle nie veel van die virus weet nie en dus nie hul mening daaroor kan uitspreek nie.

Die media is dus vir die plaaswerker ' $n$ belangrike bron van inligting ten opsigte van MIV/VIGS.

\section{Respondente se mening oor die omvang van MIV/VIGS op plase teenoor stedelike gebiede}

Op 'n vraag of die plaaswerker dink dat MIV/VIGS meer in stede as op plase aangetref word, het $92 \%$ van die respondente aangedui dat MIV/VIGS wel meer in stede voorkom en daar min of geen gevalle van MIV/VIGS op plase voorkom nie. Die volgende redes vir die tendens is verstrek:

- $71 \%$ was van mening dat daar meer mense in stede is en die kanse op infektering dus groter;

- $10 \%$ het aangedui dat slegs mense in die stede aan die siekte sterf;

- $9 \%$ het aangedui dat prostitusie in stede voorkom en dit as rede aangevoer;

- $2 \%$ het aangedui dat mense van die stede dié op plase infekteer;

- $1 \%$ van die respondente het te kenne gegee dat MIV/VIGS nie bestaan nie.

Slegs $4 \%$ van die respondente het aangedui dat MIV/VIGS in stede sowel as op plase voorkom en 3\% dat hulle te min van MIV/VIGS weet en dus nie hul mening daaroor kan uitspreek nie.

Wat die navorsers hieruit aflei, is dat die plaaswerker MIV/VIGS as 'n virus beskou wat in stede ontstaan en wat geen gevaar vir die plaaswerker inhou nie. Heckman (1998:2) is van mening dat die taak van organisasies wat voorkomingsintervensie implementeer, bemoeilik word, aangesien die inligting wat in die projekte vervat is, uiteraard nie konkreet (visueel) uitgebeeld kan word nie, en mense gevolglik dink dat MIV geen bedreiging vir hul gemeenskap inhou nie en hulle dus onbewus is van talle probleme wat MIV-geïnfekteerde persone in landelike gebiede ervaar.

\section{Die ontstaan van MIV/VIGS}

Op 'n vraag of respondente weet waar MIV/VIGS ontstaan het, het $83 \%$ te kenne gegee dat hulle nie weet nie. Nege (9\%) was van mening dat dit ontstaan het as gevolg van persone wat verskeie bedmaats het. Ander het prostitusie, straf van die voorvaders, buitelanders en onwettige immigrante as redes vir die ontstaan van MIV/VIGS aangevoer. 


\section{Wyses van oordrag}

Die kennis van plaaswerkers ten opsigte van oordragwyses van MIV/VIGS is getoets en die volgende resultate is verkry:

\section{TABEL 4}

WYSES VAN OORDRAG

\begin{tabular}{|l|c|c|c|}
\hline Stelling & Ja & Nee & Onseker \\
\hline Kan jy MIV/VIGS kry van 'n muskiet of 'n hond? & $69(69 \%)$ & $23(23 \%)$ & $8(8 \%)$ \\
\hline $\begin{array}{l}\text { Kan jy MIV/VIGS kry deur dieselfde toilet as iemand wat MIV/VIGS het, } \\
\text { te gebruik? }\end{array}$ & $28(28 \%)$ & $64(64 \%)$ & $8(8 \%)$ \\
\hline $\begin{array}{l}\text { Kan jy MIV/VIGS kry deur met 'n stukkende deel van jou vel aan iemand } \\
\text { wat MIV/VIGS het se bloed of liggaamvloeistof te raak? }\end{array}$ & $81(81 \%)$ & $15(15 \%)$ & $4(4 \%)$ \\
\hline $\begin{array}{l}\text { Kan jy MIV/VIGS kry deur iemand wat MIV/VIGS het met die hand te } \\
\text { groet? }\end{array}$ & $14(14 \%)$ & $82(82 \%)$ & $4(4 \%)$ \\
\hline Kan jy MIV/VIGS kry deur iemand met MIV/VIGS te soen? & $35(35 \%)$ & $59(59 \%)$ & $6(6 \%)$ \\
\hline Kan jy MIV/VIGS kry deur iemand wat MIV/VIGS het se spoeg? & $57(57 \%)$ & $36(36 \%)$ & $7(7 \%)$ \\
\hline $\begin{array}{l}\text { Kan jy MIV/VIGS kry deur borde, messe en vurke van iemand wat } \\
\text { MIV/VIGS het, te gebruik? }\end{array}$ & $33(33 \%)$ & $62(62 \%)$ & $5(5 \%)$ \\
\hline Kan MIV/VIGS van die ma na die baba oorgedra word? & $90(90 \%)$ & $5(5 \%)$ & $5(5 \%)$ \\
\hline $\begin{array}{l}\text { Kan jy MIV/VIGS kry deur naalde te deel met 'n persoon wat MIV/VIGS } \\
\text { het? }\end{array}$ & $87(87 \%)$ & $9(9 \%)$ & $4(4 \%)$ \\
\hline
\end{tabular}

Volgens die reaksies, soos hieronder aangedui, kan afgelei word dat sommige van die plaaswerkers oor ' $\mathrm{n}$ redelike mate van kennis ten opsigte van die oordrag van MIV/VIGS beskik:

- 64\% van die respondente het aangedui dat MIV/VIGS nie deur middel van 'n toilet oorgedra kan word nie;

- $81 \%$ het aangedui dat MIV/VIGS deur met die stukkende deel van jou vel aan iemand wat geïnfekteer is se bloed of liggaamvloeistof te raak oorgedra kan word;

- $82 \%$ het aangedui dat MIV/VIGS nie deur 'n handdruk oorgedra kan word nie;

- $59 \%$ het aangedui dat MIV/VIGS nie oorgedra kan word deur 'n MIV/VIGS persoon te soen nie;

- $90 \%$ het aangedui dat die virus tydens geboorte van die moeder na die baba oorgedra kan word.

Aangesien 69\% van die respondente verkeerdelik aangedui het dat MIV/VIGS deur 'n hond of muskiet oorgedra kan word en 57\% dat MIV/VIGS deur middel van spuug versprei kan word, blyk wanopvattings te bestaan oor die wyses waarop MIV/VIGS oorgedra kan word.

In Pletzer (2003:257) se ondersoek het hy ook bevind dat volwassenes bo die ouderdom van 15 jaar oor 'n redelike algemene kennis rakende MIV/VIGS beskik, maar dat wanopvattings steeds voorkom. Sewe en dertig persent (37\%) van die volwasse vroue het gedink dat die virus deur middel van die muskiet oorgedra kan word.

\section{Kondoom-gebruik}

Op 'n vraag of die plaaswerker weet wat 'n kondoom is, het slegs $9 \%$ aangedui dat hulle geen kennis dra van 'n kondoom nie. Alhoewel $73 \%$ die gebruik van kondome aanmoedig, het $69 \%$ 
aangedui dat hulle nie kondome tydens seksuele omgang gebruik nie. Redes wat aangevoer is vir die nie-gebruik van kondome is:

- dat dit hulle die plesier ontneem;

- dat hulle vrees dat die kondoom in die vrou se geslagsdele sal vassit;

- dat, wanneer die vrou aandring op die gebruik van 'n kondoom, die man dit as wantroue in hom beskou;

- dat kondoom-gebruik nie nodig is as 'n persoon slegs een bedmaat het nie.

Dit het uit die studie geblyk dat baie van die respondente die kondoom as $100 \%$ beveiliging teen MIV/VIGS beskou. Dit is dus 'n wanopvatting wat onder die plaaswerkergemeenskap voorkom. Naidoo (soos aangehaal deur Strydom, 2003:66) beaam dit met die volgende stelling: "Condoms are also not $100 \%$ safe and even a minute break in the latex is sufficient to allow significant passage of HIV-infection through the membrane of the condom."

'n Totaal van $21 \%$ respondente het aangedui dat die voorbehoedpil en geboortebeperkinginspuiting MIV/VIGS wel kan voorkom.

Weereens bevestig die bevindinge dat daar talle wanopvattings ten opsigte van MIV/VIGS onder die plaaswerkergemeenskap voorkom.

\section{Infektering deur MIV/VIGS ten opsigte van geslag}

Drie en vyftig (53\%) respondente het aangedui dat beide geslagte getalsgewys eweredig geïnfekteer word. Twee en twintig (22\%) respondente is van mening dat meer mans as vroue geïnfekteer word, en wel weens ontrouheid aan hul maat. Vyf en twintig (25\%) respondente was tereg van mening dat meer vroue as mans geïnfekteer word. Redes wat hiervoor gegee is, is die volgende, naamlik:

- dat vroue verskeie bedmaats het vir finansiële gewin;

- weens vroue se fisiese samestelling;

- dat vroue dikwels die slagoffers van verkragting is.

Die plaaswerkers stem dus nie saam met die stelling wat in die literatuur (Strydom, 2002:247; Whiteside \& Sunter, 2000:11) gemaak word, naamlik dat meer vroue as mans deur die virus geïnfekteer word nie. Rispel (2006:3) skryf die volgende in hierdie verband: "Women have become the face of the epidemic in Africa, and around $59 \%$ of all adults living with HIV in sub-Saharan Africa are women. Baie vroue het meer as een bedmaat ter wille van finansiële sekuriteit. In so 'n geval dra dit by tot die vrou se ekonomiese potensiaal (Buseh et al., 2001:120). Daar is dikwels ook 'n groot ouderdomsgaping tussen vrouens en hulle mans, wat meebring dat mans die mag het en nie bereid is om met die vrouens oor veilige seks te onderhandel nie (Rispel, 2006:25).

\section{Die toets vir MIV/VIGS}

Op 'n vraag na hoe respondente te werk sal gaan om vas te stel of hulle MIV-positief is, het $53 \%$ aangedui dat hulle vir 'n bloedtoets sal gaan, $42 \%$ dat hulle vir 'n ondersoek by 'n dokter of kliniek sal gaan en $5 \%$ dat hulle nie weet hoe om te werk te gaan nie.

\section{Die mening van respondente daaroor of geïnfekteerde persone van MIV/VIGS kan herstel}

Op 'n vraag of geïnfekteerde persone van MIV/VIGS kan herstel, het 23\% aangedui dat 'n persoon wel kan herstel en $73 \%$ dat 'n persoon nie kan herstel nie. Vier (4\%) van die respondente was nie seker of 'n persoon wel genees kan word nie. 
170

Die respondente het aangedui dat 'n persoon op die volgende wyses van MIV/VIGS genees kan word, naamlik:

- deur medikasie te neem en 'n voorgeskrewe dieet te volg (10\%);

- deur medikasie te neem en voortaan net een bedmaat te hê (4\%);

- deur medikasie te neem, 'n voorgeskrewe dieet te volg en voortaan net een bedmaat te hê $(1 \%)$

- deur antiretrovirale middels te gebruik (3\%);

- deur die geïnfekteerde persoon se spanning te verlig deur hom/haar met sy daaglikse take te help (1\%);

- deur omgang te hê met iemand wat nie met die virus geïnfekteer is nie (2\%);

- deur geloof in God te hê dat Hy jou sal genees (1\%).

Respondente se mening oor hul kennis

- Twee en tagtig (82\%) was van mening dat hulle kennis oor die virus gebrekkig is en nog meer daarvan te wete sal wil kom.

\section{HOUDINGS EN OORTUIGINGS}

Die volgende resultate is verkry met die meting van houdings en oortuigings van plaaswerkers ten opsigte van MIV/VIGS:

TABEL 5

HOUDINGS EN OORTUIGINGS

\begin{tabular}{|l|l|c|c|c|}
\hline & \multicolumn{1}{|c|}{ Ja } & Nee & Onseker \\
\hline 6.3 .1 & Behoort MIV-positiewe persone gratis behandeling te ontvang? & $57(57 \%)$ & $38(38 \%)$ & $5(5 \%)$ \\
\hline 6.3 .2 & $\begin{array}{l}\text { Persone wat vermoedelik MIV-positief is, behoort verplig te } \\
\text { word om hulle te laat toets. }\end{array}$ & $99(99 \%)$ & $1(1 \%)$ & $0(0 \%)$ \\
\hline 6.3 .3 & $\begin{array}{l}\text { Daar behoort meer programme oor MIV/VIGS op televisie en } \\
\text { oor die radio aangebied te word. }\end{array}$ & $98(98 \%)$ & $2(2 \%)$ & $0(0 \%)$ \\
\hline 6.3 .4 & $\begin{array}{l}\text { MIV-positiewe persone behoort nie saam met ongeïnfekteerde } \\
\text { persone te werk nie. }\end{array}$ & $65(65 \%)$ & $35(35 \%)$ & $0(0 \%)$ \\
\hline 6.3 .5 & $\begin{array}{l}\text { Jy behoort ingelig te word daaroor as iemand wat saam met jou } \\
\text { werk MIV-positief is. }\end{array}$ & $79(79 \%)$ & $21(21 \%)$ & $0(0 \%)$ \\
\hline 6.3 .6 & $\begin{array}{l}\text { Dink u dat persone wat onder die invloed van alkohol verkeer, } \\
\text { meer geneig is om by seksuele aktiwiteite betrokke te raak? }\end{array}$ & $71(71 \%)$ & $19(19 \%)$ & $10(10 \%)$ \\
\hline 6.3 .7 & Is dit vir u belangrik dat u maat MIV-negatief moet wees? & $79(79 \%)$ & $20(20 \%)$ & $1(1 \%)$ \\
\hline 6.3 .8 & Sou u bevriend wou wees met 'n MIV-positiewe persoon? & $66(66 \%)$ & $34(34 \%)$ & $0(0 \%)$ \\
\hline 6.3 .9 & Voel u jammer vir mense wat MIV-positief is? & $100(100 \%)$ & $0(0 \%)$ & $0(0 \%)$ \\
\hline 6.3 .10 & $\begin{array}{l}\text { Die regering moet meer doen om die verspreiding van MIV te } \\
\text { voorkom? }\end{array}$ & $100(100 \%)$ & 100 & 100 \\
$(100 \%)$ & $(100 \%)$ \\
\hline 6.3 .11 & 'n MIV-positiewe persoon kan met die blote oog geëien word? & $11(11 \%)$ & $89(89 \%)$ & $0(0 \%)$ \\
\hline
\end{tabular}

Positiewe reaksies is op die volgende stellings getoon:

- Ek voel jammer vir geïnfekteerde persone (100\%);

- Meer programme oor MIV/VIGS moet op televisie en radio angebied word (98\%);

- Die regering moet meer doen om MIV/VIGS te bekamp (100\%);

- Ek sal bevriend wil wees met MIV-positiewe persone (66\%);

- MIV-positiewe persone behoort gratis behandeling te ontvang (57\%);

- Dit is belangrik dat my maat MIV-negatief moet wees (66\%). 
Negatiewe reaksies is op die volgende stelling getoon:

- MIV-positiewe persone behoort nie saam met ongeïnfekteerde persone te werk nie (65\%). Ander interessante feite is dat $99 \%$ van die respondente meen dat mense wat vermoedelik MIV/VIGS-positief is, verplig moet word om hulle te laat toets, $79 \%$ dat hulle graag sou wou weet as geïnfekteerde persone saam met hul werk en $71 \%$ dat persone onder die invloed van alkohol meer geneig is om by seksuele aktiwiteite betrokke te raak. Slegs $11 \%$ van die respondente het aangedui dat 'n MIV-positiewe persoon met die blote oog geëien kan word.

Met inagneming van getalle wat voorstanders is van die MIV-toets, veral ten opsigte van die werksituasie, blyk daar ook vrees onder die gemeenskap voor te kom vir moontlike infektering. Laasgenoemde hou ook verband met die wyse van oordrag ten opsigte van MIV/VIGS.

Op die vraag of respondente hul status sou bekend maak indien hulle positief sou wees, het $40 \%$ aangedui dat hulle nie sou nie. Die rede hiervoor is die vrees vir verwerping deur die gemeenskap. Laasgenoemde is tydens die ondersoek uitgedruk as: "hulle sal vir my lag", "hulle sal van my skinder", "hulle sal bang wees vir my".

Hierdie vrees vir verwerping hou verband met stigmatisering. Beskrywende studies oor MIV/VIGS-stigma in ontwikkelende lande dui daarop dat gebrekkige kennis gepaard met die vrees vir die dood meebring dat oortuigings ontstaan dat oordrag toevallig kan plaasvind, en daarom wil mense geïnfekteerde persone en situasies vermy (Uys, Chirwa, Dlamini, Greeff, Kohi, Holzemer, Makoae, Naidoo \& Phetlhu, 2005:12).

Op 'n vraag of die respondente dink dat MIV/VIGS 'n straf van die voorvaders is, het $24 \%$ bevestig dat dit wel die geval is, aangesien die gemeenskap nie meer die tradisies van die voorvaders onderhou nie. Een van die tradisies is "die maak van rou". As 'n gesinslid sterf, moet die gesinslede 'n stukkie lap vir 'n tydperk van 30 dae aan hul klere heg. Tydens die rouperiode mag man en vrou geen seksuele omgang hê nie, want dit kan ongeluk oor die huis bring of selfs tot nog 'n sterfte lei.

Die gebrek aan kennis lei daartoe dat mense glo dat MIV/VIGS 'n vloek is wat oor 'n persoon uitgespreek is. Dit lei daartoe dat tradisionele genesers geraadpleeg word, wat gevolglik verdere gevare vir die verspreiding van MIV/VIGS kan inhou.

Op die vraag of ouers met hul kinders oor MIV/VIGS praat, het $60 \%$ "ja" geantwoord en $16 \%$ "nee". Die oorblywende $24 \%$ het te kenne gegee dat hulle kinders te klein is of dat hulle nog nie kinders het nie.

Op die vraag of respondente met hul kinders oor seksuele aangeleenthede praat, het 59\% "ja" geantwoord en $17 \%$ "nee". Die oorblywende $24 \%$ het te kenne gegee dat hulle kinders te klein is of dat hulle nog nie kinders het nie.

Alhoewel daar nie 'n spesifieke vraag was om die tendens te toets nie, is die meeste plaaswerkers van mening dat 'n kind eers vanaf 14-jarige ouderdom kennis van MIV/VIGS en seksuele aangeleenthede moet opdoen.

Selelo (soos aangehaal deur Forcheh, 2003:20) bevestig dat ouers in die algemeen met hul kinders oor seksuele aangeleenthede praat, maar dat kommunikering met meisies oor die onderwerp eers tydens puberiteit plaasvind, wat volgens die ouers tussen die ouderdomme 14 en 15 jaar is. Inligting wat aan hul kinders oorgedra word, is ' $n$ waarskuwing teen ongewenste swangerskappe en sluit min of geen inligting oor MIV/VIGS in. Volgens die Department of Health (2001) is die verspreiding van MIV/VIGS 22\% vir mense in die ouderdomsgroep 15-49 
jaar, terwyl die Nelson Mandela-studie (2002) soos aangehaal deur Avert (2005:7) 15\% as gemiddeld vir hierdie ouderdomsgroep aandui. Laasgenoemde statistiek is skerp teenstrydig, maar tog wys beide syfers dat die verspreidingsyfer onder dié ouderdomsgroep relatief hoog is.

Op 'n vraag waarop die respondente moontlike oplossings moet gee om die epidemie hok te slaan, is die volgende voorgestel, naamlik:

- dat voorligting oor kondoom-gebruik op plase gegee moet word en dat dit beskikbaar gestel moet word (14\%);

- dat die boodskap van een bedmaat beklemtoon moet word (5\%);

- dat die regering medikasie moet bekom wat die virus kan voorkom (7\%);

- dat daar nie werklik 'n oplossing is nie (56\%);

- dat inligting oor MIV/VIGS verskaf moet word (15\%);

- dat 'n dokter vroegtydig geraadpleeg moet word (1\%);

- dat mense hul status bekend moet maak (2\%).

As die hoeveelheid plaaswerkers $(56 \%)$ wat meen dat daar nie werklik 'n oplossing vir die bekamping van MIV/VIGS is nie in gedagte gehou word, kan die navorsers die afleiding maak dat die gemeenskap hulpeloosheid en hopeloosheid ervaar ten opsigte van die bekamping van MIV/VIGS. Deur die mense te bemagtig kan die negatiewe houding omgekeer word.

\section{BESPREKING}

MIV-verspreiding is die hoogste in die Vrystaat Provinsie (14,9\%) naas Gauteng met 'n syfer van $(14,7 \%)$ en Mpumalanga met (14,1\%). 'n Groot persentasie van die Vrystaat Provinsie- en Gauteng-bewoners is in informele nedersettings woonagtig, wat 'n groot risikofaktor is vir MIV-infektering (Human Sciences Research Council of South Africa, 2003).

Die Bothaville-Kroonstad-distrik in die Vrystaat Provinsie beskik oor ' $n$ groot aantal plaasgemeenskappe, aangesien die provinsie bekend is vir sy landbou-aktiwiteite. Uit die voorafgaande is dit duidelik dat die plaaswerker ook deur die MI-virus geaffekteer word. Die navorsers is van mening dat die hoë getalle van infektering verband hou met die gebrek aan kennis onder plaaswerkers. South Africa Human Rights Commission (2004) steun die mening van die navorsers met die volgende stelling: "Die gebrek aan inligting ten opsigte van MIV/VIGS is kommerwekkend en dui daarop dat die uitdagings wat die pandemie stel in plaasgemeenskappe nie gekonfronteer word nie."

Dit wil voorkom of die kommersiële plaaswerkers minder bewus is van die MI-virus. Van die plaaswerkers het te kenne gegee dat hulle nog nooit werkswinkels of byeenkomste in hierdie verband bygewoon het nie (Barnabas, 2003:113). Die meeste kommersiële boere het geen beleid of strategieë beplan om MIV/VIGS te bekamp nie (Barnabas, 2003:124). Volgens dieselfde skrywer moet die boer aangemoedig word om voorsiening te maak vir opvoedkundige en ander strategieë om plaaswerkers bewus te maak van die gevare wat MIV/VIGS inhou, asook met betrekking tot die verspreiding daarvan en ook ten opsigte van die langtermyneffek wat dit op landbouproduksie het.

'n Paneel wat deur die Menseregte Kommissie saamgestel is, het bevind dat die wet ontoereikend voorsiening mak vir die beskerming van mense en hul regte. Die groot uitdaging vir die realisering daarvan lê in die oorkoming van struikelblokke wat die plaaswerkergemeenskap ondervind. Die gebrek aan mag, dienste, toegang, bronne en kennis is slegs enkele aspekte hiervan (South Africa Human Rights Commission, 2004). 


\section{GEVOLGTREKKINGS}

Een honderd volwassenes uit die plaaswerkergemeenskap is by die ondersoek betrek. Alhoewel die steekproef verteenwoordigend van die plaaswerkergemeenskap in die Bothaville-Kroonstad-distrik was, kan die resultate nie veralgemeen word nie. Die steekproef was te klein en nie ewekansig geselekteer nie.

Sommige van die vrae was van 'n sensitiewe aard; dit is dus moeilik om te sê of die vrae eerlik beantwoord is.

Uit die ondersoek blyk daar wanopvattings oor die oordrag van die MI-virus te wees. Onsekerheid heers onder plaaswerkers oor wat MIV/VIGS werklik is. Twee en tagtig (82\%) van die respondente het te kenne gegee dat hulle oor gebrekkige kennis ten opsigte van MIV/VIGS beskik.

Alhoewel die gemeenskap die nodige empatie teenoor slagoffers van die virus betoon, heers 'n mate van vrees nogtans vanweë die feit dat $79 \%$ graag daaroor ingelig wil wees as 'n geïnfekteerde persoon saam met hulle werk en $99 \%$ van die respondente aandui dat mense wat vermoedelik MIV/VIGS het, hulle moet laat toets. Die vrees ontstaan by respondente weens 'n gebrek aan kennis.

Alhoewel $73 \%$ van die respondente die gebruik van 'n kondoom aanmoedig, het slegs $30 \%$ aangetoon dat hulle telkens tydens seksuele omgang wel 'n kondoom gebruik.

\section{AANBEVELINGS}

Op grond van voorgenoemde bevindinge en gevolgtrekkings word die volgende aanbevelings gedoen:

- Die plaaslike regering moet daadwerklike pogings ten opsigte van die voorkoming van MIV/VIGS onder plaaswerkers aanwend om voorkomingsprojekte te loods asook te befonds.

- Professionele voorligters soos maatskaplike werkers en opgeleide vrywilligers moet by projekte betrek word om plaaswerkers se kennis ten opsigte van MIV/VIGS deur middel van groepwerk en gemeenskapwerk as metodes te verbreed.

- 'n Groepwerk-intervensieprogram kan vir die plaaswerkergemeenskap aangebied word. Die doel sal wees om lede met kennis oor MIV/VIGS te bemagtig, om hulle lewensvaardighede te ontwikkel en om die regte houding by die plaaswerkergemeenskap ten opsigte van MIV/VIGS te kweek. Die volgende onderwerpe kan ingesluit word: selfkennis, kommunikasie, ouerskapvaardighede, huweliksverhouding, effektiewe geldbesteding, kennis oor MIV/VIGS en seksvoorligting aan kinders.

- Plaaswerkers se kultuur en taal rakend MIV/VIGS-opvoeding moet in ag geneem word by die samestelling van voorkomingsprojekte om sodoende ' $n$ doeltreffende impak te kan maak.

- Gemeenskapsprojekte moet onderneem word om die maatskaplike funksionering van die plaaswerkers te verbeter. Die mobilisering van dienste en die verskaffing van ontspanningfasiliteite is slegs enkele van die vele aspekte wat die plaaswerker se funksionering kan bevorder.

- Die taak van die maatskaplike werker ten opsigte van die voorkoming van MIV/VIGS by die plaaswerkergemeenskap is van kardinale belang. Die maatskaplike werker beskik oor die vaardigheid en kundigheid om 'n groot verandering in die land se MIV/VIGS vraagstuk mee te bring. 


\section{BIBLIOGRAFIE}

AVERT. 2005. South Africa HIV/AIDS statistics. South Africa. [Web:] http://www.avert.org/safricastats.htm [Accessed: 5 September 2005].

BARNABAS, O. 2003. Government leaders in Namibia responding to the HIV/AIDS epidemic. Namibia: University of Namibia Press.

BERSTEIN, A.J. \& VAN ROOYEN, C.A.L. 1994. Social culture factors and their importance in working with people with aids in South Africa. Social Work/Maatskaplike Werk, 30(4):372.

BUSEH, A.G., GLASS, L.K. \& MCELMURRY, B.J. 2001. Educating woman about HIV/AIDS: some international comparison. Health Care for Women International, 23(2):173. [In EBSCOHost: Academic Search, Full display: http//www.-sa.ebsco.com] [Accessed: 14 January 2005].

DEPARTMENT OF ECONOMIC DEVELOPMENT AND TOURISM. NORTH WEST PROVINCE. 2004. North West population trends and development report, 2003/2004. Mafeking: North West Population Unit.

DE VOS, A.S., STRYDOM, H., FOUCHE, C.B. \& DELPORT, C.S.L. 2005. Research at grass roots: for the social scienses and human service professions. Pretoria:Van Schaiks.

EVIAN, C. 2000. Primary AIDS Care: a practical guide for primary health care personnel in the clinical and supportive care of people with HIV/AIDS. Johannesburg: Jacana Education.

FORCHEH, N.I.A. 2003. The prevention of HIV infection among teenage girls in Botswana: An overview of related interventions. Botswana: University of Botswana. (Dissertation - MSc)

FURBER, A.S., HODGSON, I.J., DESCLAUX, D.S. \& MUKASA, D.S. 2004. British Medical Journal, 329(7477):1281. [In EBSCOHost: Academic Search, Full display: http://www-sa.ebsco.com.] [Accessed: 14 Januarie 2005].

GRINNELL, R.M. 1993. Social work research and evaluation. Itasca: Peacock.

HECKMAN, T.G. 1998. Barriers to care among persons living with HIV/AIDS in urban and rural areas. Aids Care, 10(3):11. [In EBSCOHost: Academic Search, Full display: http://www-sa.ebsco.com] [Accessed: 24 Julie 2004].

HUMAN SCIENCES RESEARCH COUNCIL OF SOUTH AFRICA. 2003. Research to inform HIV/AIDS prevention, care and the impact mitigation. South Africa. [Web:] http://www.hsrc.ac.za/research/npa/SAHA/news/keynote.html. [Accessed: 18 Julie 2005].

LOUW, M. 2004. MIV/VIGS lê landbou in Afrika lam, sê verslag. Beeld, 14 Maart.

MAKHUBELE, J.C. 2004. The impact of culture on the prevention and treatment of HIV/AIDS amongst people in low-resourced areas: a social work perspective. Potchefstroom: Noordwes-Universiteit. (Ongepubliseerde MA-verhandeling)

NUWE WOORDEBOEK VIR MAATSKAPLIKE WERK. 1995. Kaapstad: CTP Book Printers.

PELSER, W. 2004. Boere 'moet staat lei oor grond'. Rapport, 5 September. 
PLETZER, K. 2003. HIV/AIDS/STD knowledge, attitudes, beliefs and behaviours in a rural South African adult population. South African Journal of Psychology, 33(4):250-260. [In EBSCOHost: Academic Search, Full display: http://www-sa.ebsco.com] [Accessed: 15 Januarie 2005].

PODILE, M.P. 2004. The knowledge and attitudes of high school learners regarding people living with HIV/AIDS. Potchefstroom: Noordwes-Universiteit. (Ongepubliseerde MA-verhandeling)

RAATH, H. 2001. Riglyne vir die maatskaplikewerkhantering van die psigo-sosiale behoeftes van HIV/VIGS blootgestelde adolessente. Potchefstroom: Noordwes-Universiteit. (Ongepubliseerde MA-verhandeling)

RISPEL, L. 2006. Education sector responses to HIV and AIDS: learning from good practices in Africa. London: Commonweallth Secretariat.

ROUNDS, K.A., GALINSKY, M.J. \& STEVENS, L.S. 1991. Linking people with AIDS in rural communities: The telephone group. Social Work/Maatskaplike Werk, 36(1):13. [In EBSCOHost: Academic Search, Full display: http://www.-sa.ebsco.com] [Accessed: 15 Januarie 2005].

ROUX, A.A., VENTER, C.S. \& WESSELS, C.C. 2001. A group work programme for HIV/AIDS patients. The Social Work Practitioner Researcher/Die Maatskaplike Werk Navorser Praktisyn, 13(2):33-47.

ROUX, A.A. 2002. Evaluering van 'n groepwerk-hulpverleningsprogram met MIVpositief/ VIGS-pasiënte. Potchefstroom: Noordwes-Universiteit. (Ongepubliseerde D.Philproefskrif)

ROYSE, D. 1995. Research methods in social work. Chigaco: Nelson Hall.

RYKE, E.H. 2004. The social niche of farm dweller's: A social work strengths approach. Potchefstroom: Noordwes-Universiteit. (Ongepubliseerde D.Phil-proefskrif)

SAS INSTITUTE. 2005. The SAS System for Windows Release 9.1 TS Level 1 MO. Cary, NC, USA: SAS Institute.

SCHRAM, S.G. 2004. African ag co-ops leading fight against HIV/AIDS. Rural Cooperatives, 71(1):2. [In EBSCOHost: Academic Search, Full display: http://wwwsa.ebsco.com] [Accessed: 28 September 2004].

SEYAMA, K.D.V. 2006. Vulnerability to HIV amongst African people in rural areas: The Thusana project. Potchefstroom: Noordwes-Universiteit. (Ongepubliseerde D.Phil-proefskrif) SOUTH AFRICA. Department of Health. 2001. HIV/AIDS \& STD. Strategic plan for South Africa 2000. Cape Town: CTP Book Printers.

SOUTH AFRICA. Department of Health 2004. Report: National HIV and Syphilis Antenatal Sero-prevalence survey in South Africa. Pretoria: Department of Health.

SOUTH AFRICA HUMAN RIGHTS COMMISSION. 2004 [Web:] http://www.sahrc.org.za/farming inquiry foreword [Accessed: 18 Julie 2005].

STRYDOM, C. 2002. Evaluation of an HIV/AIDS program for students at a tertiary institution with emphasis on peer group involvement. Potchefstroom: NoordwesUniversiteit. (Ongepubliseerde D.Phil-proefskrif) 
176

STRYDOM, C. \& STRYDOM, H. 2004. The psycho-social circumstances of car guards: Interventive roles of the social worker. Social Work/Maatskaplike Werk, 40(3):319.

STRYDOM, H. 2000. The knowledge base of high school pupils in the North West Province on HIV/AIDS. The Social Worker Practitioner-Researcher/Die Maatskaplike Werk Navorser-Praktisyn, 12(3):195-207.

STRYDOM, H. 2003. HIV/AIDS and South African adolescents: Attitudes and information needs. Maatskaplike Werk/Social Work, 39(1):59.

STRYDOM, H., CRONJÉ, F.J., ROUX, A.A., STRYDOM, C. \& WESSELS, C.C. 2005. Die wisselwerking tussen MIV/VIGS en armoede: 'n Psigososiale perspektief. Maatskaplike Werk/Social Work, 41(1):68.

UNAIDS. 2004. Report on the global HIV/AIDS Epidemic. Geneva:UNAIDS.

USAID. 2002. Voluntary counselling and testing in Uganda. [Web:] http://www.usaid.gov/press/releases/2002/fso20523-i.html.

UYS, L., CHIRWA, M., DLAMINI, P., GREEFF, M., KOHI, T., HOLZEMER, W., MAKOAE, L., NAIDOO, J.R. \& PHETLHU, R. 2005. "Eating plastic," "Winning the lotto," "Joining the WWW"... Descriptions of HIV/AIDS in Africa. Journal of the Association of Nurses in AIDS Care, 16(3):11-21.

WESSELS, C.C. 2003. Die opstel en evaluering van 'n maatskaplike-bemagtigingsprogram vir gesinne van MIV-positiewe/VIGS-pasiënte. Potchefstroom: NoordwesUniversiteit. (Ongepubliseerde D.Phil-proefskrif)

WHITESIDE, A. \& SUNTER, C. 2000. AIDS: the challenge for South Africa. Cape Town: Human \& Rousseau.

Dr Corinne Strydom, me Leana Noguiera, dr Adrie Roux, Skool vir Psigo-sosiale Gedragswetenskappe, Potchefstroomkampus van die Noordwes-Universiteit, Potchefstroom, Suid-Afrika. 